\section{Federation University ResearchOnline}

\section{https://researchonline.federation.edu.au}

Copyright Notice

This is the published version of:

Sandhu, H., Clarke, B., Baring, R., Anderson, S., Fisk, C., Dittmann, S., Walker, S., Sutton, P., Kubiszewski, I., \& Costanza, R. (2018). Scenario planning including ecosystem services for a coastal region in South Australia. Ecosystem Services, 31, 194-207.

Available online: https://doi.org/10.1016/j.ecoser.2018.04.006

Copyright @ 2018 Elsevier B.V. This is an open-access article distributed under the terms of the Creative Commons Attribution License (CC BY 4.0) (http://creativecommons.org/licenses/by/4.0/). The use, distribution or reproduction in other forums is permitted, provided the original author(s) or licensor are credited and that the original publication in this journal is cited, in accordance with accepted academic practice. No use, distribution or reproduction is permitted which does not comply with these terms. 


\title{
Scenario planning including ecosystem services for a coastal region in South Australia
}

\author{
Harpinder Sandhu ${ }^{\text {a,c,* }}$, Beverley Clarke ${ }^{b}$, Ryan Baring ${ }^{a}$, Sharolyn Anderson ${ }^{c}$, Claire Fisk ${ }^{c}$, Sabine Dittmann ${ }^{\text {a }}$, \\ Stewart Walker ${ }^{\mathrm{a}}$, Paul Sutton ${ }^{\mathrm{c}, \mathrm{d}}$, Ida Kubiszewski ${ }^{\mathrm{e}}$, Robert Costanza ${ }^{\mathrm{e}}$ \\ ${ }^{a}$ College of Science and Engineering, Flinders University, Adelaide, Australia \\ ${ }^{\mathrm{b}}$ College of Humanities and Social Sciences, Flinders University, Adelaide, Australia \\ ${ }^{\mathrm{c}}$ School of Natural and Built Environments, University of South Australia, Adelaide, Australia \\ ${ }^{\mathrm{d}}$ University of Denver, CO, USA \\ ${ }^{\text {e } C r a w f o r d ~ S c h o o l ~ o f ~ P u b l i c ~ P o l i c y, ~ A u s t r a l i a n ~ N a t i o n a l ~ U n i v e r s i t y, ~ C a n b e r r a, ~ A u s t r a l i a ~}$
}

\section{A R T I C L E I N F O}

\section{Article history:}

Received 30 June 2017

Received in revised form 30 March 2018

Accepted 14 April 2018

Available online 26 April 2018

\section{Keywords:}

Coastal zone

Conservation

Economic value

Evidence-based decisions

Resource management

Saltmarshes

\begin{abstract}
A B S T R A C T
Coastal regions provide vital ecosystem services for the human well-being. Rapid economic growth and increasing population in coastal regions is exerting more pressure on coastal environments. Here we develop four plausible scenarios to the year 2050 that address above issues in the northern Adelaide coastline, South Australia. Four scenarios were named after their characteristics, Lacuna, Gold Coast SA, Down to Earth, and Green E Gold. Lacuna and Gold Coast SA. Economy declined significantly in Lacuna, whereas, there is highest annual GDP growth (3.5\%) in Gold Coast SA, which was closely followed by Green E' Gold scenario (3\%), GDP under Down to Earth grows at moderate 1.5\%. There is highest population growth in Gold Coast SA followed by Green \& Gold, Down to Earth and Lacuna. Gold Coast SA scenario led to high inequality as estimated by the Gini co-efficient of 0.45 compared to the current value of 0.33 . Ecosystem services declined rapidly under Green E Gold and Lacuna as compared to the other two scenarios. The combination of scenario planning and ecosystem services valuation provides the capacity to guide coastal planning by illustrating enhanced social, environmental and economic benefits.
\end{abstract}

(c) 2018 Elsevier B.V. All rights reserved.

\section{Introduction}

Globally, coastal ecosystems contribute to many vital ecosystem services including but not only; water purification, climate regulation, erosion control, habitat provision, recreation and cultural activities (Luisetti et al., 2013; Liquete et al., 2013; Costanza et al., 2014). Coastal ecosystems typically include saltmarshes, mangroves, nearshore reefs, seagrass beds, and sandy beaches. Despite the high ecological and economic value of coastal wetlands (Costanza et al., 2014), there is continuous decline in their structure and function, mainly due to human activities (Barbier et al., 2011). Moreover, human population growth and coastward migration is increasing rapidly, driven by rapid economic development in coastal regions. This growth is exerting enduring pressure on coastal environments (Neumann et al., 2015). Currently about $40 \%$ of global human population lives within $100 \mathrm{~km}$ of the coast (Neumann et al., 2015). It is likely that pressures on coastal ecosys-

\footnotetext{
* Corresponding author at: College of Science and Engineering, Flinders University, Adelaide, Australia.

E-mail address: harpinder.sandhu@flinders.edu.au (H. Sandhu).
}

tems will continue to increase in the future, leading to loss of biodiversity and habitats and further losses of many essential ecosystem services (Costanza et al., 2014; Ellis et al., 2015). Therefore, it is critical to plan strategically to manage coastal environments so that they continue to provide social, environmental and economic benefits to residents living along the coast through the provision of ecosystem services.

Scenario planning is a structured process to explore and evaluate alternative futures that may be influenced by various unknown drivers (Kahane, 2004; O’Brien, 2000; Costanza et al., 2015). Due to these unknown drivers and uncertainty, scenario planning differs from other types of planning such as forecasting, projections, and predictions. Scenario planning is designed to explore plausible futures, not probable ones (Peterson et al., 2003). There is growing use of scenario planning as a decision-making tool at national, regional and global levels in a participatory process that involves policy makers, academics, and the wider community (Reed et al., 2013; Ruiz-Mallén et al., 2015; Podolak et al., 2017). For example, at the national scale in Australia scenarios have been developed to explore individual and community orientation to technological and economic growth (Costanza et al., 2015). Regional scale scenarios 
have explored different drivers of change relevant to the focus area including irrigation futures of the Goulburn Broken Region, Australia (Wang et al., 2006), social-ecological sustainability of the Guiana Shield, South America (Mistry et al., 2014), Latin America Environment Outlook (UNEP, 2010), the Great Barrier Reef (Bohensky et al., 2011), North American grasslands (Phillips-Mao et al., 2016), Swedish forests (Carlsson et al., 2015), marine spatial planning in southern region of Los Lagos, Chile (Outeiro et al., 2015), using spatial valuation of ecosystem services into regional planning and development in Finland (Tammi et al., 2017) and land use scenarios for Chile (Martinez-Harms et al., 2017). Global scale scenarios have been developed to study the state of environment, biodiversity and economic value of ecosystem services and underlying drivers such as climate change and economic choices with large scale impacts (MEA, 2005; IPCC, 2000; Kubiszewski et al., 2016, 2017). Much of the scenarios have focused on terrestrial ecosystems and there has been a paucity of scenarios for coastal environments that utilise the ecosystem services approach (Arkema et al., 2015).

The northern Adelaide coastline in the Gulf St Vincent of South Australia is a unique region that supports a vast extent of largely intact, coastal saltmarsh and temperate mangrove area in Australia. These saltmarshes and mangroves support several species that are rare and endemic to this region (Edyvane, 1999; Fotheringham and Coleman, 2008; Caton et al., 2009). The Gulf St Vincent also supports significant numbers of national and international migratory and resident shorebirds, recently recognized as the Adelaide International Bird Sanctuary (Purnell et al., 2015). Yet, the northern Adelaide coastline is threatened by numerous processes and actions, such as sea-level rise, potential for acid sulfate soils, species loss, loss of ecosystem services, and development pressure (Caton et al., 2009; Poch et al., 2009). Also, a large-scale salt works industry recently ceased operation, creating challenges and providing opportunities for coastal restoration. To support decision making in this context and better manage the northern coastal Adelaide region, four plausible scenarios were developed in a participatory workshop held over four days, engaging multiple stakeholders from government, non-government, industry, university, community groups and others. The four contrasting scenarios were developed in anticipation of assisting local planning processes to achieve a balance of social, environmental and economic sustainability in the northern coastal Adelaide region to the year 2050. We also estimated the implications of these scenarios and their land use and management assumptions for the value of ecosystem services as one aspect of the assessment. We demonstrated a case study to show how ecosystem services can fit into a regional scenario planning process within a rather limited budget. The contribution of this study is an example of the use of ecosystem services in scenario planning, and not in advancing methods for the valuation of ecosystem services.

\section{Study area and methods}

\subsection{The Barker Inlet and port river estuary region}

The Barker Inlet and Port River Estuary (BIPE) is located in the northern Adelaide coastline of South Australia (Fig. 1). The coastal wetlands in the BIPE region are identified as hosting conservation hotspots due to both the existence and extent of an array of coastal wetlands, and supratidal habitats and species (Caton et al., 2009). The region is a characteristically flat and low-lying low-energy coast with meso-tidal range and has large interconnected areas of seagrass meadows, mudflats, fringing mangroves and coastal saltmarsh supporting a diverse range of aquatic and terrestrial fauna (Bloomfield and Gillanders, 2005; Shepherd et al., 2008). In addition, the saltmarshes provide an important buffer between land and aquatic environments. They effectively filter catchment run-off, thus protecting Gulf waters and seagrasses from nutrient and sediment loads (Fotheringham and Coleman, 2008). The BIPE region is also important as significant refuge and feeding grounds for at least 51 species of birds, both resident and migratory (Shepherd et al., 2008; Coleman and Cook, 2009; Purnell et al., 2015). In recognition of the significance of birds of this region, the Adelaide International Bird Sanctuary was established in 2015. The BIPE also supports a uniquely urban resident population of dolphins and in 2005, the Adelaide Dolphin Sanctuary was declared under legislation (Kemper et al., 2008; Cribb et al., 2013). BIPE is also a significant nursery for many recreationally and commercially important fish species (Connolly, 1994; Fowler and Short, 1996; Jackson and Jones, 1999).

BIPE is a highly-modified ecosystem due to its history of industrialisation. The region is characterised by an expanse of salt ponds (recently decommissioned), a natural-gas fuelled electricity generation plant, naval ship and submarine building facilities, that are scheduled to expand, fuel storage depots and a wastewater treatment plant. New proposals for further expansion of industrial and residential land releases, a major road realignment plan (a Northern Connector route), and redevelopment of the salt ponds promote growth and expansion of both industrial and urban aspects of the region. South Australia's Strategic Plan, 'The 30Year Plan for Greater Adelaide' (Government of South Australia, 2010), forecast a significant increase in population growth, road and rail traffic and economic expansion in northern Adelaide.

The region's development history has already had a detrimental effect on habitats and species. The process of land reclamation, invasive species, the incursion of mangroves into saltmarsh, coastal acid sulphate soils, hydrological changes, off-road vehicles, waste disposal, and agricultural grazing have served to damage habitats and reduce biodiversity (Edwards et al., 2001; Shepherd et al., 2008). Based on the IPCC (Intergovernmental Panel on Climate Change) projections for sea-level rise using medium and high values in the IPCC range, the BIPE will be subject to increasing sea level rise and further land subsidence (Department of Climate Change, 2009).

Land use zoning in this region is complex. Zones include: rural, industry (including mining), metropolitan open space/recreation, conservation, residential, country townships, rural living, coastal, commercial and mixed uses (Coleman and Cook, 2009). Land tenure in the region comprises both freehold titles (both private and public) and Crown Land; some of the titled and untitled land (freehold and Crown) is overlain by 7 or 21 -year mining leases (Coleman and Cook, 2009). A freehold title means the land owner owns the property outright in perpetuity, whereas, the Crown Land is land that is owned and managed by the South Australian government. Some of these mineral tenements have recently been rescinded with the closure of the Dry Creek Salt Fields. This mosaic of land use allocation and title complicate management and planning. Adding to the complications of mixed use, competition for resources and complex zoning, responsibility for management of the land in the BIPE region is divided between state and local jurisdictions and administered by many different agencies (Edyvane, 1999).

\subsection{Scenario planning process}

A scenario planning workshop for the BIPE region was conducted at Flinders University in the City of Adelaide over four days from 8-11 February 2016. Fifty-five people attended the workshop representing stakeholders from State Government (21 participants), Local Government (5), Industry (2), Universities (18), NGOs (3) and other community groups (6). The workshop commenced 


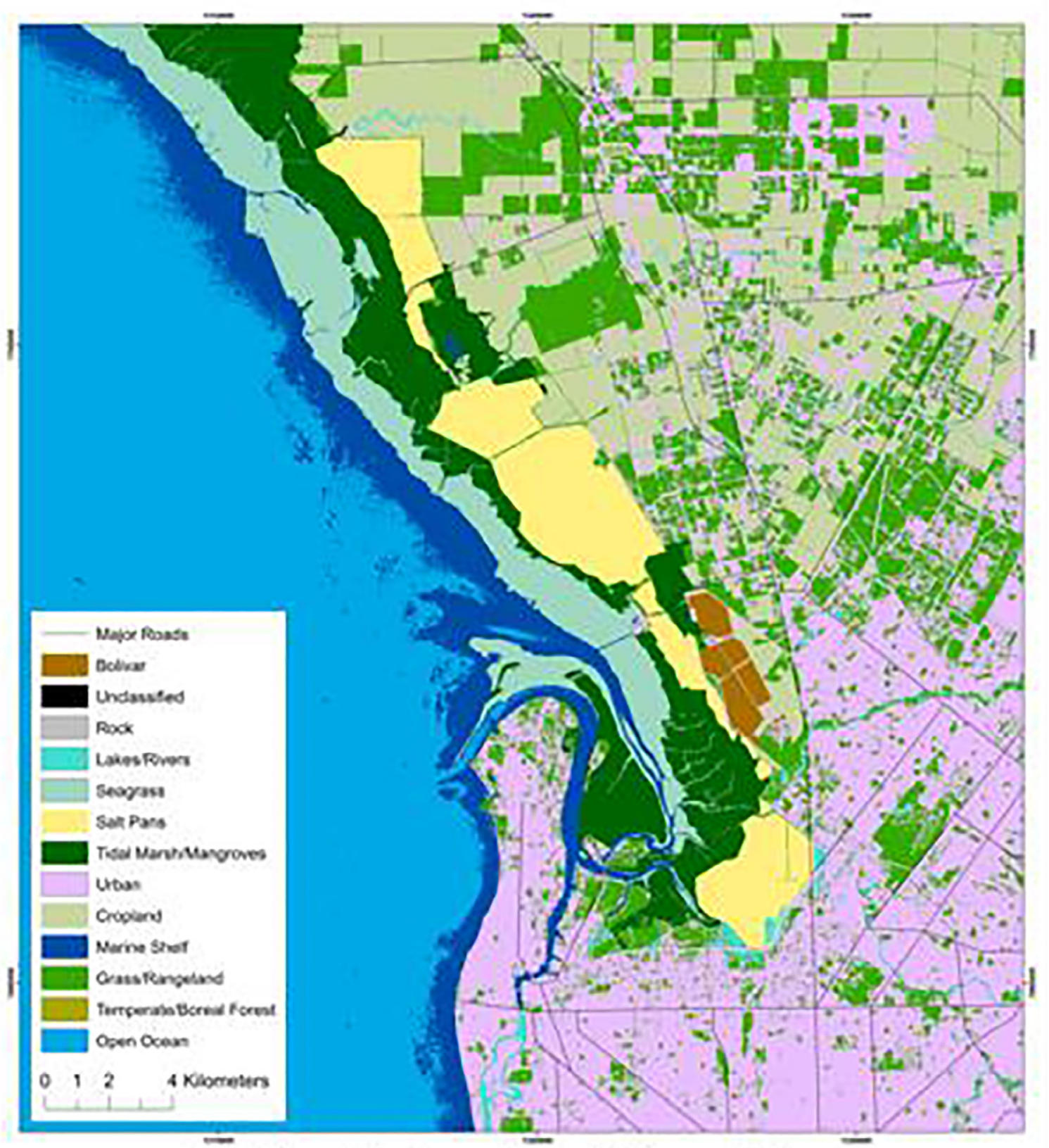

\section{Barker Inlet and Port River Estuary}
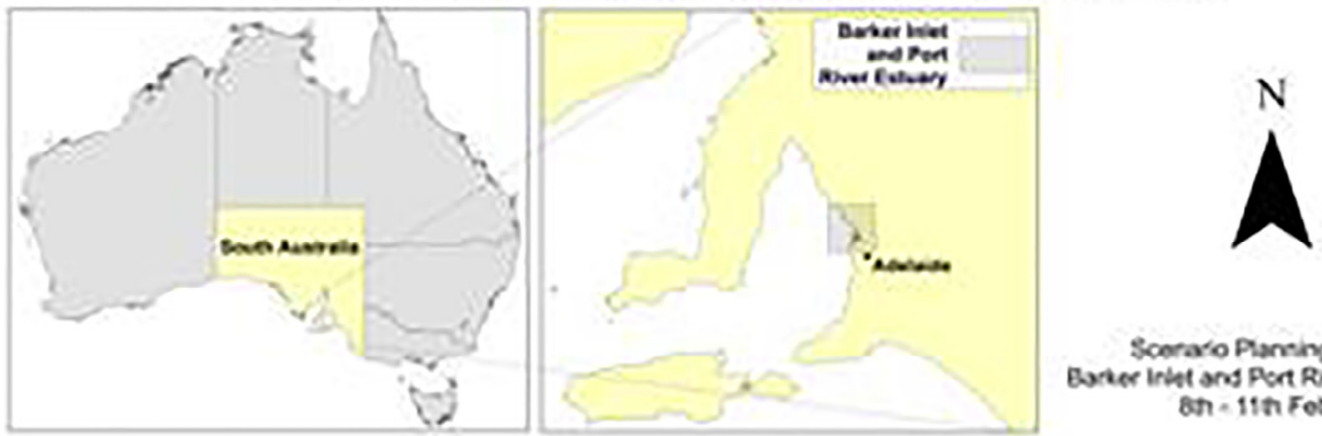

Scoraso Planeing Wrokahap Bareer intat and Plort River Estaon 8n- 11th Fotruary 2016

Fig. 1. Barker Inlet and Port River Estuary of Adelaide, South Australia, with the land cover categories in early 2016. 
with context setting presentations on the ecology of the BIPE region, the ecosystem services relevant to the area, and anticipated future developments in the region. These presentations were delivered by academic members of the working group, and key state and local government representatives.

We followed three steps process in developing scenarios for the future of BIPE region. These were: defining the scope of the scenarios, detailed description of each scenario, and quantifying the provision of ecosystem services due to land use change.

\subsubsection{Scope of the scenarios}

We defined the scope of the scenarios analysis as the exploration of environmental benefits from the provision of 17 ecosystem services from the land use change to 2050 (Costanza et al., 2014) and economic benefits in the BIPE region from the ongoing development processes.

A map of current land cover (2016) in the BIPE region $(125,895$ ha) was created from a geodatabase that captured a range of survey data, satellite imagery and existing GIS datasets (Fig. 1). A mixed method approach was used to analyse the imagery by applying a combination of the maximum likelihood classification algorithm and an expert system to incorporate further data that produced a map with $>90 \%$ accuracy. Only validated data were used in the image classification process. This map was used as the starting point of discussion for the development of scenarios. The major land cover categories in the BIPE region are; seagrass, bare bottom estuary, saltpans, saltmarsh, mangroves, built environment, agriculture, mixed green space, open fresh water, and wasteland (acid sulphate soils). Initially, the focus of the workshop was to be on the immediate coastal zone of the BIPE region, but it became clear during workshop discussions that effects of the scenarios extend to the agricultural hinterland of the northern Adelaide plains, as well as to connectivity with the city of Adelaide.

For this workshop, 17 different ecosystem services were focused upon after Costanza et al. (2014). Following on classification of ecosystem services by the Millennium Ecosystem Assessment (MEA, 2005) and the Economics of Ecosystems and Biodiversity (TEEB, 2010), these ecosystem services were grouped into five categories; 1) Regulating services (gas regulation, climate regulation, disturbance regulation, water regulation, water supply, erosion control, waste treatment, pollination, biological control), 2) Habitat services (habitat/refugia), 3) Provisioning services (food production, raw materials, genetic resources), and 4) Cultural services (recreation, cultural), and 5) Supporting services (soil formation, nutrient cycling). Supporting services are necessary for the production of other ecosystem services, therefore, they do not lead to direct benefit for society and hence are not included to estimate the current and future economic value of ecosystem services in the study area.

\subsubsection{Description of scenarios}

Scenario construction commenced with the four preliminary scenarios sketched out at the start of the workshop, with two axes - relating to environmental and economic benefits (Fig. 2a):

Scenario 1: Low attention to economic and environmental benefits;

Scenario 2: Low attention to environmental benefits and high attention to economic benefits;

Scenario 3: Low attention to economic benefits and high attention to environmental benefits; and

Scenario 4: High attention to environmental and economic benefits.

Participants were randomly allocated to one of four groups (12 to 13 people per group and one scenario per group) and asked to discuss and respond to the following questions: (a)

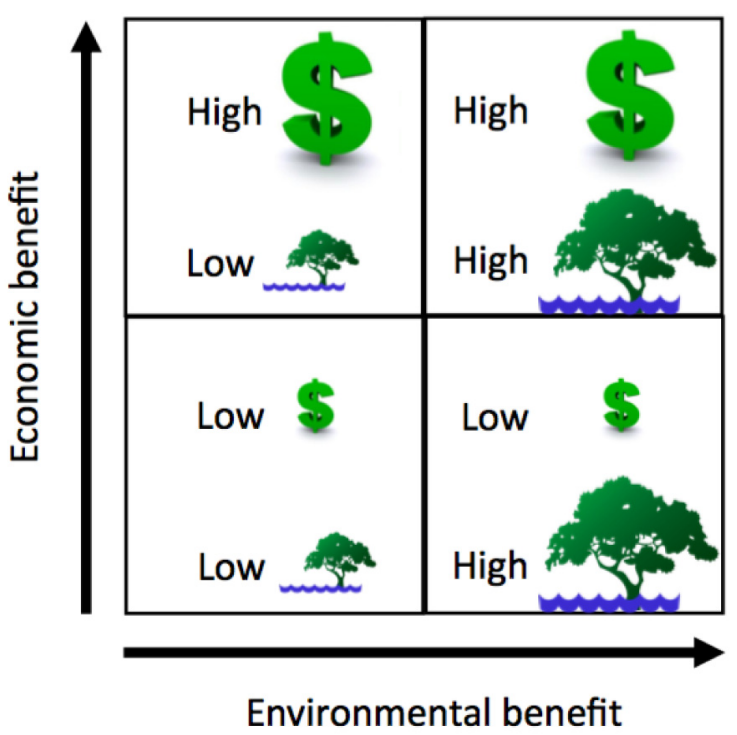

(b)

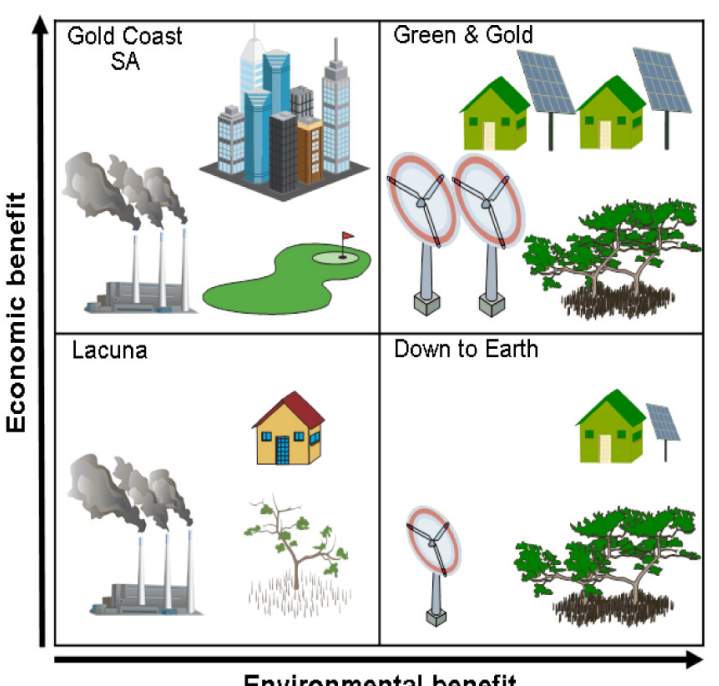

Environmental benefit

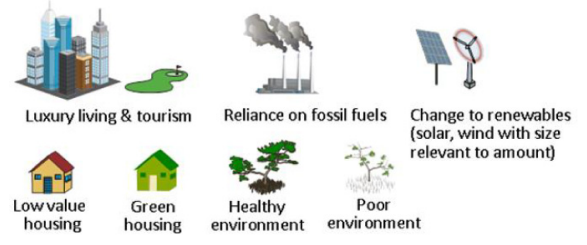

Fig. 2. a) Four plausible future scenarios at the start of the workshop, and b) Four scenarios as developed at the workshop.

1) What would be the key characteristics of the region under their allocated future scenario?

2) What name would you give to describe your scenario?

The four groups, in turn, presented their ideas back to the whole workshop including a working name and key characteristics that defined their scenario. Based on these characteristics, scenario depictions were further elaborated (Fig. 2b).

For each scenario, detailed narratives or stories were drafted around these characteristics to bring the scenarios to life. The narratives were presented back to the whole workshop and refined based on further discussion and contributions of all workshop attendees. The key attributes for each scenario considered were: economy, 
governance, population, built environment, natural environment. These attributes align with the approaches of the Millennium Ecosystem Assessment (MEA, 2005) and other approaches for assessing scenario outcomes (e.g., Bohensky et al., 2011). Each scenario was further refined using the attributes, land cover and narratives.

\subsubsection{Quantifying land use change and ecosystem services}

To obtain stakeholder assessment of the effects of each scenario on land use and ecosystem services to 2050, participants were asked to discuss two key questions for each scenario:

1) What/Where/How would activities/land use changes occur under this scenario?

2) What would be the implications of these changes for ecosystem services?

Each scenario was evaluated in two ways:i) using the 2011 unit values estimated by Costanza et al. (2014) and only changing land cover. Land cover classes (seagrass, bare bottom estuary, saltpans, saltmarsh, mangroves, built environment, agriculture, mixed green space, open fresh water, and wasteland) were chosen in alignment with the biomes used by Costanza et al. (2014), to allow the use of a benefit transfer model to calculate the ecosystem services values for each land cover class. The emphasis of the study was more on the scenario planning and less on the ecosystem services valuation. Therefore, the application of global values to this study area was used to understand the general magnitude of ecosystem services as one aspect of the assessment of each scenario. For this reason, the valuation of ecosystem services, of necessity, was rather quick and simplified assessment as used in other similar scenario planning exercises (Bohensky et al., 2011; Costanza et al., 2015; Kubiszewski et al., 2016, 2017). For each land cover class (Fig. 1), the number of pixels were extracted, converted to hectares (ha) and this area was then multiplied by the unit values 2011 unit values estimated by Costanza et al. (2014) (converted to 2016 Australian dollar) for ecosystem services flow per ha of the corresponding land cover class. The unit values used here include regulating, habitat, provisioning and cultural services only and exclude supporting services. This map was used as the starting point of discussion for the scenarios.ii) changing both unit values and land use. Workshop attendees then estimated changes in land cover (seagrass, bare bottom estuary, saltpans, saltmarsh, mangroves, built environment, agriculture, mixed green space, open fresh water, and wasteland), population, GDP, and other variables such as inequality (Gini co-efficient; Gini, 1936) under each scenario to 2050 for the region. A Gini co-efficient of zero means perfect equality, 1 means total inequality. Value of ecosystem services in these scenarios were estimated by change in the land cover type and change in the unit value of ecosystem services (including regulating, habitat, provisioning and cultural services only and excluding supporting services). The change in unit values depended on the land and marine management policies likely to occur in each scenario. These per cent changes were based roughly on the estimates included in the Bateman et al. (2013) study of six future scenarios for the UK, and Kubiszewski et al. (2016, 2017). These are plausible estimates of the magnitude of change that could occur under each hypothetical scenario and are not intended to be empirically derived (Kubiszewski et al., 2016, 2017).

This is a simplification of assumptions to estimate the future value of ecosystem services. However, there was a general consensus among the workshop participants that these are sufficient for assessing trade-offs between different scenarios and for understanding the magnitude of total ecosystem services values in BIPE region. More elaborate analysis can be done for future studies using various modelling tools (Turner et al. 2016; Kubiszewski et al., 2017). Similarly, supply and demand of regulating ecosystem ser- vices and some cultural services (e.g., inspiration for culture) are difficult to estimate, as these are non-rival, non-marketable. It is assumed that their unit values may not be greatly affected by the relative scarcity from reduced area (Kubiszewski et al., 2017). However, provisioning and habitat services are more likely to be affected by change in area. Therefore, for the scenario analysis, we assumed that changes in supply are the major factor and the unit values will change mainly as a function of management policies as mentioned above.

\section{Results}

\subsection{Scenario characteristics}

The four alternative future scenarios for the BIPE region were expanded with the narratives developed at the workshop (Table 1). The narratives illustrate important components such as economy, governance, population, built environment, natural environment. The scenarios were not only differentiated in relation to environmental and economic benefits of the initial scenario axes, but also by the subsequent effects on overall human well-being.

\section{(1) Scenario 1: Lacuna}

Scenario 1 began with the scaffolding: Low environmental and low economic benefits. The name Lacuna was assigned to this scenario, referring to a hiatus, or a vacuum, and is used in this instance in the sense of "nothing gets done". This is a business-as-usual scenario describing a place where the population increases under a risk averse government in a region with a stagnant economy, experiencing social and environmental degradation, and where the public has limited connection with the environment. There is increased unhappiness and mental health issues with low individual well-being.

\section{(2) Scenario 2: Gold Coast SA}

Scenario 2 began with the scaffolding: Low environmental and high economic benefits. The name Gold Coast SA was assigned to this scenario with reference to Australia's Eastern Gold Coast, and other similarly highly developed coastlines. The name is synonymous for a place with much new development characterised by high-density, high-rise housing for maximum financial gain. The priorities of this scenario are high-class tourism and development of commercial recreational facilities with little regard for the natural environment. Few individuals prosper and unhappiness is growing.

\section{(3) Scenario 3: Down to Earth}

Scenario 3 began with the scaffolding: High environmental and low economic benefits. The name Down to Earth was assigned to this scenario, referring to a wholesome, green and clean community characterised by small sustainable neighbourhoods. This scenario is characterised by public and private investment in emerging green technologies expecting modest economic benefits. Emphasis is placed upon environmental protection. Large tracts of land are set aside as national parks, closed from public use and development. The community rapidly developed a sense of place and belonging. Participation of people to take on civic duties and share in civic responsibilities promotes more active and healthy population, improved social cohesion.

\section{(4) Scenario 4: Green and Gold}

Scenario 4 began with the following scaffolding: High environmental and high economic benefits. The name Green and Gold was 
Table 1

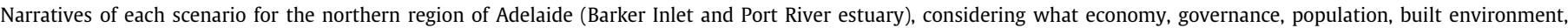
natural environment could be like by 2050 .

\begin{abstract}
Lacuna
Economy. Struggling with continuing economic decline, the South Australian government became risk averse. The closure of industry and car manufacturing devastated the local economy. Local exports were uncompetitive on the global market. Local industries stagnated due to a combination of an inability to compete with cheap imports, and a decline in demand for manufactured goods, produce, and minerals. Shipping activity through the Port slowed significantly. Employment opportunities were concentrated in the city resulting in long average commuting distances and times. There was a lack of job opportunities and large numbers of long term and generational unemployed. The cost of living rose, with water, food, and energy prices escalating
\end{abstract}

Governance. Local governments vying with each other over limited resources resulted in short term thinking that overruled collaborative and strategic planning. There was an absence of clear vision and leadership. The community is disengaged from government. A burgeoning of government agencies has resulted in excessive bureaucracy with lack of coordination and communication. State and local governments were responsible for providing infrastructure to new growth areas. The State government had also committed to upgrading existing infrastructure that serviced the wider Adelaide population. Constrained federal, state and local government budgets could not meet the plans for infrastructure provision in these new growth regions

Population. Offsetting the city's ageing population, the State Government encouraged skilled migrants and opened the northern region of Adelaide to new housing development. The in-migration segregated socio-economic groups. Lower socio-economic groups were pushed to the metropolitan fringe to more affordable housing, disconnected from community centers and essential services. New growth housing was designed to attract the skilled migrant population. The region experienced an increase in the social divide with the separation and segregation of housing types

Built environment. Urban expansion into productive land has pushed horticultural industries to the fringes. Water restrictions also forced conversion of much horticulture to dryland cropping. New affordable housing developments are constructed in isolated pockets in disconnected peri-urban areas, temporarily boosting the construction industry. Limitations from state funding restrict the construction of public and transport infrastructure. Public transport and infrastructure were limited by stretched State budgets, leading to high reliance on private transport and limited provision of recreational facilities. This has consequences for people's health. Transport infrastructure is limited to roadways, as insufficient funding is available for railways

Natural environment. No single body has responsibility to manage the salt ponds, no decommissioning was undertaken and they lie fallow, leaving the area as a resource recovery infill site. Limited investment for planning and management of storm water facilities and sea level rise has led to frequent flooding events. Local economies and transport infrastructure are regularly disrupted and the most effected residences abandoned. The continuing rise in sea level intensifies the impact of these floods each year. The waste water treatment plant has been expanded to accommodate the larger population. Lack of finances for management leads to intermittent midge swarms and reduced visibility on adjacent roads. The Northern Connector motorway has been constructed with extensive levies preventing coastal retreat. Land reclamation from dredging and sand spit formation has provided opportunities for some new salt marsh formation and bird habitat. Some of the unmanaged salt ponds have offered value for birds. The mangroves continue to act as nurseries for fish species. A 'coastal squeeze' resulted from increased urban expansion abutting the coast. The design of the Northern Connector impeded the potential for coastal retreat. Mangroves migrated landward responding to sea level rise and out competed much of the salt marsh habitat. Crown lands seaward of the salt ponds were degraded through increased access and use by recreational users attracted to the low-lying coastal topography (trail bikes, horse riders and dog walking). Increased access also encouraged incursions of pest plants and animals. Development activity in the salt ponds led to exposure and activation of acid sulphate soils that polluted waterways and caused fish kills. Additional nutrients from an unsewered, newly industrialised site and the waste water treatment plant also reduced water quality in the Gulf Well-being. Individuals feel isolated and lack a sense of community. The mental and physical health of the general public decreased. People are unhappy. Persona and housing security measures were needed to protect against crime. Residents living in close proximity to unmanaged salt ponds had a higher rate of mosquito borne diseases. There is limited uptake of opportunities for environmental awareness

Down to Earth

Economy. Leaders of the northern region of Adelaide promoted a collective vision based upon simplicity in lifestyle choices that included decreasing material consumption, whilst increasing awareness of the importance of the local environment. The region embraced this vision by creating a circular, 'global'

\section{Gold Coast SA}

Economy. Australian governments were in alignment working towards economi recovery by aggressively pursuing a market centred approach to governing. The region was open for business. The Government welcomed foreign investment. It provided additional capital for economic growth, and created employment opportunities, and promoted healthy competition. The Federal Government through the Foreign Investment Review Board approved unlimited international investment in the region allowing access to global supply chains and markets. The region was primed as a site for commercial development and economic growth Governance. Local government development plans reflected strategies that maximised opportunities for urban and industrial expansion and development. Much regulatory red tape has been removed and replaced by one-stop-shop planning approvals and streamlined processes attractive to investors and property developers. Government investment was directed towards promoting the business and enterprise potential of the region. Unprofitable, government subsided ventures were discontinued including the Adelaide Dolphin and Bird Sanctuaries, replaced by profit maximising initiatives

Population. A social divide between the affluent and the economically and socially deprived has emerged in the region and the gap is increasing. The exclusive gated waterfront apartments and estates are contrasted by isolated pockets of affordable housing at the margins. Low socio-economic groups have been disenfranchised and the situation worsened under the Government's economic policy reform. Financial hardship has placed severe stress on families reflected by an increased rate of criminal activity and illicit drug use Built environment. Prized coastal lands were opened up to developers in an extensive urban expansion campaign. Underutilised coastal wetlands were released for profitable uses including high-rise apartment blocks and canal estates, capitalising on water frontage, and a commercial hub for retail ventures. Tourist facilities and spaces have been optimised to suit a range of consumer interests from a jet-ski 'playground', and world-class golf course to motor-cross facilities. The Port was revitalised through an urban renewal project. The Port River inlet was deepened to allow access for larger cruising vessels and to accommodate increased shipping, servicing the needs of intensified local mining activities. 'Productive use' was the catch phrase for the region. Infrastructure from the downsized salt production was transformed to aquaculture and bio-fuel farms, generating a commercial return. Additional power and fresh water generation formed part of the government's job creation scheme

Less financially productive horticulture has been pushed to the periphery. To accommodate this urban expansion, the waste water treatment plant has been moved northward along with the airport, repositioned for an extended runway. Introduction of new technology, the addition of much needed infrastructure and aggressive promotion of the region's skills base served to strengthen its competitive edge. Where necessary the shoreline was modified to facilitate waterfront development. In a trade-off to maximise waterfront views, sea walls and groynes were needed to protect valuable assets vulnerable to sea level rise. Crown land was opened to urban expansion and heritage residences replaced by high density living. Transport infrastructure investment was boosted creating an efficient system that supported economic development. The Northern Connector motorway attracted linear expansion and opened up commercial opportunities. The growth of commerce and industry shepherded new housing estate development into areas previously used for horticulture. The channeling of foreign investment into construction of new homes for Australians increased the demand for greenfield sites. Unused salt ponds were remediated to meet this demand. To reduce the region's vulnerability to flooding and to minimise wastewater treatment costs, a new system of infrastructure pipes now diverts directly to the Gulf

Natural environment. Coastal wetlands and shorebird habitat were substituted for profitable urban and industrial uses. Responding to sea level rise, mangroves encroach the fragmented saltmarsh habitats. Seagrasses have died back in response to elevated nutrient loads entering the Gulf; much of the seabed is exposed. Problems associated with contaminated dredged materials and acid sulphate soils prove a challenge to commercial enterprises. Higher numbers of invasive species are present on land and in the Gulf

Well-being. There is increase in mental health issues. Few individuals prosper and unhappiness is growing. Environmental awareness discouraged

\section{Green and Gold}

Economy. There has been a call for radical transformation away from incremental and business-as-usual approaches in responding to climate change and global warming. Australia has accepted its international obligations to reduce its carbon emissions. Local Governments recognised the opportunity to lead Adelaide into a 


\section{Down to Earth}

Economy. Leaders of the northern region of Adelaide promoted a collective vision based upon simplicity in lifestyle choices that included decreasing material consumption, whilst increasing awareness of the importance of the local environment. The region embraced this vision by creating a circular, 'global' economy, committing to resource conservation, maximising efficiency of water and energy resources, and creating a zero-waste system. Resources were sourced locally

Governance. Decision-making was inclusive and participatory; residents' values were appreciated and the community shared a sense of belonging. Strict environmental regulations were created to govern commercial enterprises Population. The vision included decent and affordable housing for all socioeconomic and ethnic groups and an improvement in employment opportunities for disadvantaged groups

Built environment. A temporary surge the construction industry was seen with the development of new green housing estates and the restoration of environmentally damaged urban areas. Local employment opportunities were created within the green economy (eco-tourism, land management, sustainable technologies, and renewable energy production). The government established incentives to provide retrofitting of existing housing to increase energy efficiency and water efficiency further reducing the region's ecological footprint. The councils also committed to the ' 20 min city' concept whereby residents could undertake or access most activities needed for a fulfilling lifestyle within walking, cycling or short public transport distance from where they lived. The flow on effects of the 20 min city design included fewer cars on the road, reduced traffic congestion and vehicle emissions, and improved health outcomes. The livability of the carefully designed spaces improved the mental and physical health of people living in the region. New housing developments were constructed to have a minimal footprint, abiding by strict building codes with high environmental standards. Construction of compact urban neighbourhoods with few environmental impacts. Eco-engineering solutions were applied to places constructed prior to the 20 min city developments

Natural environment. With an increased demand for organic green produce, the horticulture industry intensified. Polluting industries and fossil fuel power plants were decommissioned. The productivity of fisheries increased with enhanced storm and waste water management, as well as the burgeoning of small-scale water quality improvement schemes using filter feeders. Inefficient croplands were converted to grass- and bushlands. The national park served as a draw car bringing tourists. Cultural and creative industries were strengthened. In actively pursuing the 20 min city concept, urban design was concentrated in high to medium density mixed-use nodes and corridors. Mixed land use provided people with access to employment; people had the ability to undertake activities locally. The construction of interesting and livable spaces attracted residents. The emphasis on ease of access mobility and transport facilities resulted in a series of linked commuting 'greenways' and pathways that connected communities to services and recreational amenities, parks and the surrounding natural environment. Renewable energy initiatives including localised smart distribution networks, power production from decentralised sources and provision of sufficient storage options supplied the region's electricity demands. Protection buffers were retrofitted to manage sea level rise and flooding events with the added benefit of providing ecosystem service benefits. Storm water management was designed for reuse or engineered to minimise direct discharge to the Gulf. Increased natural water flows within the estuary eliminated the need for dredging of the channel. In recognition of the services provided by the important coastal wetlands of the region their protection was given high priority. Old industrial sites were remediated and specially designed engineering solutions assisted in the ecological restoration of the salt ponds into a series of wetlands with north to south flows, and tidal flushing. The creation of the national park covering parts of the region, guaranteed the long-term health of coastal habitats. The mangroves and salt marshes flourished providing plentiful and varied habitat suitable for migratory and shore birds. The reduction of pollutants entering the Gulf improved coastal water quality resulting in seagrass recolonisation. Low impact activities (kayaking, birdwatching, etc.) were encouraged, while high impact activities (jet skiing, trail biking, etc.) were restricted or managed to limit damage to the natural environment

Well-being. The councils collectively developed services and facilities that promoted social inclusion, personal wellbeing, and social equity. The community rapidly developed a sense of place and belonging. Education and recreational facilities were incorporated into the national park and surrounding regions. People were actively encouraged to take on civic duties and share in civic responsibilities. This resulted in more active and healthy population, improved social cohesion

\section{Green and Gold}

Economy. There has been a call for radical transformation away from incremental and business-as-usual approaches in responding to climate change and global warming. Australia has accepted its international obligations to reduce its carbon emissions. Local Governments recognised the opportunity to lead Adelaide into a carbon neutral future while driving economic and employment opportunities. Global demand for green products and innovative technologies provide a viable market. The region has successfully undergone economic renewal following the transition from mining, and traditional manufacturing sectors. There has been a stimulus in job creation and growing employment opportunities in green housing construction and concentrated development of the renewable energy sector. The region is iconic as a smart and green economic hub. The region's brand is both internationally and nationally acclaimed, annually attracting large numbers of visitors. The South Australian Government has provided strong incentives and support to advance this. The region serves as a gateway for external markets, exporting services and innovations to partners along the East-Asian Australian flyway. Opportunities provided by the unique coastal wetlands and estuary have seen nature based tourism flourish. In the global shift to a low carbon economy, the region has made significant advancement in carbon trading in global carbon markets by protecting and restoring its valuable coastal wetlands

Governance. There is a highly active and participatory community comprising business and industry, environmental groups, indigenous people's organisations, youth groups, farmers, researchers, and local government. To chart the course of action and to provide certainty leaders are guided by a collectively designed transparent and robust MoU that is immune to political cycles. The MoU is a long term agreement based on collaboratively developed goals

Population. The local community is forward thinking, supportive and active in making decisions. There is a strong sense of community and individuals have an attachment and sense of place. Volunteerism is the norm. There is a functioning citizen science program using smart technology, that informs management and planning. Traditional cultural values and knowledge are incorporated into decision making. The values of the environment are well understood and shared. The region boasts high levels of employment, and performs positively on the socio-economic index

Built environment. Old industrial sites have been converted to manufacture components to support renewable energy industries. A solar array has been constructed on unproductive, cleared lands. The region has become a centre for biogas production, accepting waste from other parts of Adelaide. Productive agricultural land is protected and local food hubs thrive, following innovative and sustainable farming practices. The clean and green reputation of horticultural produce makes it highly sought after. Urban growth is carefully planned to avoid urban sprawl and the creation of green corridors has served to both provide convivial recreational spaces whilst reducing urban heat island effects and buffers from industrial sites. Public transport has been reinstated and upgraded offering both efficient train and tram facilities linking the region to the city. Houses are constructed for maximum energy and water efficiency

There has been a cultural mind-shift about this northern region of Adelaide. It is a broadly appreciated and iconic site for the city of Adelaide

Natural environment. Increased research funding has been channeled into the region though the Centre for Coastal Wetlands Research, a world leader in coastal saltmarsh ecology and research engaging several universities. The region serves as a functioning laboratory and provides a test-bed for research including the design of smart technologies to measure ecosystem services, blue carbon farming, fisheries management, coastal wetlands restoration, and waste water innovation. In recognition of the considerable value afforded by coastal wetlands in reducing the impacts associated with elevated sea-levels, coastal planning and policies have adopted generous buffer zones and set-backs for new development. Comprehensive coastal wetland rehabilitation programs provide effective and low-cost coastal protection. Established urban areas have been retrofitted with ecological engineering solutions protecting against natural processes. A catchment to coast continuum of recreational shared use trails has been constructed along rivers, coasts and wetlands to enhance recreational experiences. Appropriate sites for recreational vehicles and bikes have been assigned, minimising impacts on saltmarsh habitat from unregulated use. The maritime heritage of the region has been revived and historic buildings are protected and offer convivial meeting spaces. The region is listed as a Ramsar site bringing many visitors drawn to the attractions of dolphins, local and migratory birds and the unique expanse of saltmarsh. Salt ponds have been restored variously to maximise bird habitat, provide for storm water and to prevent acid sulphate soil events. Rehabilitation of the westerly salt ponds has allowed for a return to more natural tidal flushing and rejuvenation of salt marsh. Investment has been put into remediation and cleansing of contaminated lands from heavy metal contaminants

Well-being. The region boasts sophisticated environmental education facilities with mangrove boardwalk and shorebird observatory. There is a longer life expectancy and increased happiness and health among individuals 
Table 2

Land cover in the study area under current and projected change (\%) in four scenarios to 2050.

\begin{tabular}{|c|c|c|c|c|c|c|}
\hline & & \multirow{2}{*}{$\begin{array}{l}\text { Current } \\
2016 \text { (ha) }\end{array}$} & \multicolumn{4}{|c|}{ Scenarios to 2050} \\
\hline & & & Lacuna (ha) & Gold Coast SA (ha) & Down to Earth (ha) & Gold E Green (ha) \\
\hline 1 & Seagrass & 34,526 & $24,168(-30 \%)$ & $24,168(-30 \%)$ & $34,526(0 \%)$ & $34,526(0 \%)$ \\
\hline 2 & Bare bottom estuary & 19,201 & $29,559(+54 \%)$ & $29,559(+54 \%)$ & $19,201(0 \%)$ & $19,201(0 \%)$ \\
\hline 3 & Saltpans & 4232 & $0(-100 \%)$ & $0(-100 \%)$ & $0(-100 \%)$ & $0(-100 \%)$ \\
\hline 4 & Saltmarsh & 3354 & $2348(-30 \%)$ & $3019(-10 \%)$ & $6908(+106 \%)$ & $6908(+106 \%)$ \\
\hline 5 & Mangroves & 3181 & $3499(+10 \%)$ & $3181(0 \%)$ & $3402(+7 \%)$ & $3402(+7 \%)$ \\
\hline 6 & Built environment & 23,608 & $28,412(+20 \%)$ & $33,051(+40 \%)$ & $23,608(0 \%)$ & $25,261(+7 \%)$ \\
\hline 7 & Agriculture & 31,963 & $28,767(-10 \%)$ & $27,583(-14 \%)$ & $32,041(0.2 \%)$ & $31,133(-3 \%)$ \\
\hline 8 & Mixed green space & 4961 & $4465(-10 \%)$ & $4465(-10 \%)$ & $5209(+5 \%)$ & $4465(-10 \%)$ \\
\hline 9 & Open fresh water & 869 & $869(0 \%)$ & $869(0 \%)$ & $1000(+15 \%)$ & $1000(+15 \%)$ \\
\hline \multirow[t]{2}{*}{10} & Wasteland (Acid Sulphate soils) & 0 & $3809(+100 \%)$ & $0(0 \%)$ & $0(0 \%)$ & $0(0 \%)$ \\
\hline & Total & 125,895 & 125,895 & 125,895 & 125,895 & 125,895 \\
\hline
\end{tabular}
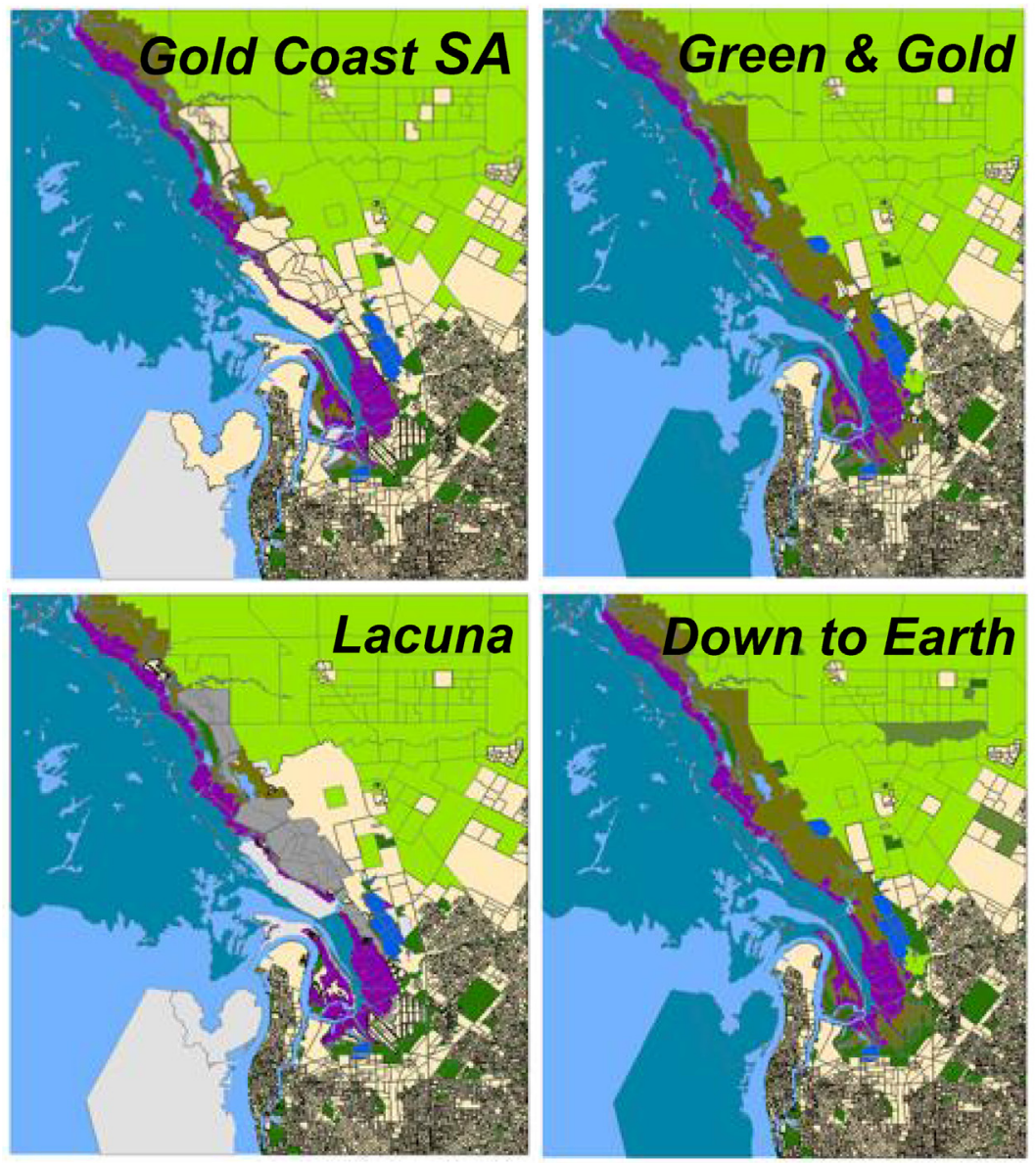

Seagrass

Bare Bottom Esturay

Mangroves

Salt Marsh

Built Environment

Open Fresh Water

Agriculture

Mixed Green Space

Fig. 3. Land use and land cover under each of the four scenarios until 2050.

assigned to this scenario, referencing the colours of an iconic Australian plant, the wattle (Acacia genus). This scenario is characterised by increased population growth and recognition that a healthy environment is crucial to the economy. Under this scenario, large public and private investments contribute to enhancing green technologies, sustainable food production, nature-based tourism, environmental restoration and sustainable housing precincts leading to full employment. Overall, individual well-being is enhanced. A strong community structure has advanced social investments into excellent education and health facilities. There is a longer life expectancy and increased happiness and health among individuals.

\subsection{Land cover change and ecosystem services under each scenario}

Following the narratives, the workshop participants considered changes in land use and cover under each of the scenarios until the year 2050 (Table 2, Fig. 3). These changes in the land cover classes allowed for estimation of ecosystem service values using the benefit transfer method (Table 3 and 4).

\subsubsection{Land cover change under each scenario}

Under the current situation, out of 10 land cover classes, seagrass has the largest area followed by agriculture and built environment (Table 2). Following on from the narratives and 
Table 3

Value of ecosystem services used in Costanza et al. (2014), which are being used in estimation of total ecosystem services values in the BIPE region.

\begin{tabular}{|c|c|c|c|c|c|}
\hline & Regulating \$/ha/yr & Habitat \$/ha/yr & Provisioning \$/ha/yr & Cultural \$/ha/yr & Current (2016) Total \$/ha/yr \\
\hline Seagrass & 35,410 & 266 & 3529 & 410 & 39,615 \\
\hline Bare bottom estuary & 74 & 0 & 132 & 132 & 339 \\
\hline Salt Marsh & 236,581 & 23,479 & 2439 & 3004 & 265,503 \\
\hline Mangroves & 236,581 & 23,479 & 2439 & 3004 & 265,503 \\
\hline Built environment & 1262 & 0 & 0 & 7864 & 9126 \\
\hline Agriculture & 1876 & 0 & 4910 & 113 & 6898 \\
\hline Mixed green space & 407 & 1577 & 1684 & 264 & 3932 \\
\hline Open fresh water & 2733 & 0 & 145 & 2967 & 5846 \\
\hline \multicolumn{6}{|c|}{ (b) Adjusted unit values of ecosystem services in each scenario to 2050.} \\
\hline & \multirow{2}{*}{$\begin{array}{l}\text { Current } \\
2016 \$ / \mathrm{ha} / \mathrm{yr}\end{array}$} & \multicolumn{4}{|l|}{ Scenarios to 2050} \\
\hline & & Lacuna $(-10 \%)$ & Gold Coast SA $(-20 \%)$ & Down to Earth $(+10 \%)$ & Gold \& Green (+10\%) \\
\hline Seagrass & 39,615 & 35,653 & 31,692 & 43,576 & 43,576 \\
\hline Bare bottom estuary & 339 & 305 & 271 & 373 & 373 \\
\hline Salt Marsh & 265,503 & 238,953 & 212,403 & 292,054 & 292,054 \\
\hline Mangroves & 265,503 & 238,953 & 212,403 & 292,054 & 292,054 \\
\hline Built environment & 9126 & 8213 & 7300 & 10,038 & 10,038 \\
\hline Agriculture & 6898 & 6208 & 5518 & 7588 & 7588 \\
\hline Mixed green space & 3932 & 3539 & 3146 & 4325 & 4325 \\
\hline Open fresh water & 5846 & 5261 & 4677 & 6430 & 6430 \\
\hline
\end{tabular}

Table 4

Total ecosystem services value under current and future scenarios to 2050 in BIPE region.

\begin{tabular}{|c|c|c|c|c|c|c|}
\hline \multicolumn{7}{|c|}{$\begin{array}{l}\text { without adjusted unit values of ecosystem services } \\
\text { Current }\end{array}$} \\
\hline & Area (ha) & 2016 (e6 \$/yr) & Lacuna (e6 \$/yr) & Gold Coast SA (e6 \$/yr) & Down to Earth (e6 \$/yr) & Gold \& Green (e6 \$/yr) \\
\hline Seagrass & 34,526 & 1368 & 957 & 957 & 1368 & 1368 \\
\hline Bare bottom estuary & 19,201 & 7 & 10 & 10 & 7 & 7 \\
\hline Salt pans & 4232 & 0 & 0 & 0 & 0 & 0 \\
\hline Saltmarsh & 3354 & 890 & 623 & 801 & 1834 & 1834 \\
\hline Mangroves & 3181 & 845 & 929 & 845 & 903 & 903 \\
\hline Built environment & 23,608 & 215 & 259 & 302 & 215 & 231 \\
\hline Agriculture & 31,963 & 220 & 198 & 190 & 221 & 215 \\
\hline Mixed green space & 4961 & 20 & 18 & 18 & 20 & 18 \\
\hline Open fresh water & 869 & 5 & 5 & 5 & 6 & 6 \\
\hline Wasteland (Acid Sulphate soils) & 0 & 0 & 0 & 0 & 0 & 0 \\
\hline Total & 125,895 & 3570 & 3000 & 3128 & 4574 & 4580 \\
\hline \multicolumn{7}{|c|}{ (b) with adjusted unit values of ecosystem services. } \\
\hline \multirow[t]{2}{*}{ Biome } & & Current & \multicolumn{4}{|l|}{ Scenarios to 2050} \\
\hline & Area (ha) & $2016(\mathrm{e} 6 \$ / \mathrm{yr})$ & Lacuna (e6 \$/yr) & Gold Coast SA (e6 \$/yr) & Down to Earth (e6 \$/yr) & Gold \& Green (e6 \$/yr) \\
\hline Seagrass & 34,526 & 1368 & 862 & 766 & 1505 & 1505 \\
\hline Bare bottom estuary & 19,201 & 7 & 9 & 8 & 7 & 7 \\
\hline Salt pans & 4232 & 0 & 0 & 0 & 0 & 0 \\
\hline Saltmarsh & 3354 & 890 & 561 & 641 & 2018 & 2018 \\
\hline Mangroves & 3181 & 845 & 836 & 676 & 994 & 994 \\
\hline Built environment & 23,608 & 215 & 233 & 241 & 237 & 254 \\
\hline Agriculture & 31,963 & 220 & 179 & 152 & 243 & 236 \\
\hline Mixed green space & 4961 & 20 & 16 & 14 & 23 & 19 \\
\hline Open fresh water & 869 & 5 & 5 & 4 & 6 & 6 \\
\hline Wasteland (Acid Sulphate soils) & 0 & 0 & 0 & 0 & 0 & 0 \\
\hline Total & 125,895 & 3570 & 2700 & 2502 & 5032 & 5038 \\
\hline
\end{tabular}

outcomes of the scenarios (Table 1), Lacuna leads to significant decrease in seagrass $(-30 \%)$, saltmarsh $(-30 \%)$, agriculture $(-10 \%)$ and mixed green space $(-10 \%)$. Saltpans disappear under this scenario. Bare bottom estuary, mangroves and built environment registers increase by $54 \%, 10 \%, 20 \%$, respectively. Waste land (acid sulphate soils) are formed (100\%). There is no change in open freshwater cover.

Under Gold Coast SA scenario, there is significant decrease in seagrass $(-30 \%)$, saltmarsh $(-10 \%)$, agriculture $(-14 \%)$ and mixed green space $(-10 \%)$. Saltpans disappear under this scenario. Bare bottom estuary and built environment registers increase by $54 \%$,
$40 \%$, respectively. There is no waste land formed under this scenario. There is no change in mangroves and open freshwater cover.

For Down to Earth, there is no change in seagrass, bare bottom estuary, built environment, agriculture. There is significant increase in saltmarsh (+106\%), and mangroves $(+7 \%)$, mixed green space $(+5 \%)$ and open freshwater cover $(+15 \%)$. Saltpans disappear under this scenario. There is no waste land formed under this scenario.

Green and Gold scenario is similar to Down to Earth, except there is increase in built environment (7\%) and decrease in agriculture $(-3 \%)$ and mixed green space $(-10 \%)$. 
6.00

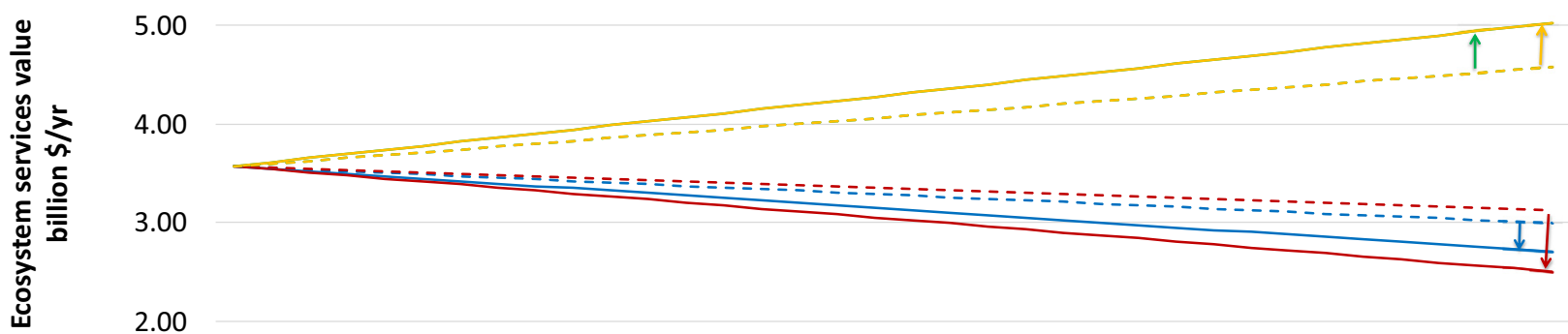

1.00

0.00

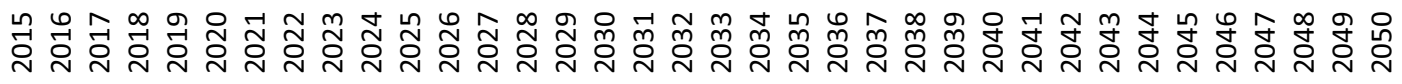

$\begin{array}{llll}\text { - Lacuna } & \text { - GoldCoast SA } & \text { - Down to Earth } & \text { Gold \& Green } \\ \text { - - Unadjusted Lacuna } & -- \text { Unadjusted GoldCoast SA } & \text { - - Unadjusted Down to Earth } & \text { - - Unadjusted Gold \& Green }\end{array}$

Fig. 4. Total annual ecosystem services value with unit values and adjusted values in the four scenarios to 2050 .

\subsubsection{Future value of ecosystem services under each scenario}

i) Using 2011 unit values and only changing land cover. Global values of ecosystem services were extracted from Costanza et al. (2014) and are presented in Table 3a. During the workshop, the total value of ecosystem services provided by BIPE region was estimated by using the 2011 unit values from Costanza et al. (2014) and only changing land cover under each scenario (Table 4a). There is decrease in the value of ecosystem services from the current level ( $\$ 3.57$ billion in 2016) to $\$ 3.0$ billion and $\$ 3.1$ billion in Lacuna and Gold Coast SA scenarios, respectively. Whereas, the Down to Earth and Green \& Gold scenarios show significantly higher ecosystem services values by 2050 ( $\$ 4.57$ billion). The scenarios differed in the fate of the commercial salt pans. Under scenarios (Down to Earth, Green $\mathcal{E}$ Gold) with restoration and conversion of salt fields to saltmarsh and mangroves, ecosystem values increased due to the higher unit value for this biome (Table 3a). Scenarios leading to loss of seagrass and other wetland habitats due to urban expansion, led to a decrease in ecosystem service values.ii) Using adjusted unit values and land cover. Based on the discussions at the workshop regarding environment and economic development, the following assumptions were considered for each of the four scenarios (Table $3 \mathrm{~b}$ ):

Lacuna: environmental degradation, and limited connection of public with the environment results in an average 10 per cent reduction in unit values from their 2011 levels.

Gold Coast SA: significant environmental degradation, and discouragement of environmental awareness to public results in an average 10 per cent reduction in unit values from their 2011 levels.

Down to Earth and Green \& Gold: improvement in overall environment and strong connection of public with the environment results in 10 per cent increase in unit values from their 2011 levels. These two scenarios did not differ on environmental improvements, therefore, the increase in unit values of ecosystem services is uniform in both.

Total value of ecosystem services estimated by using adjusted unit values are provided in Table $4 \mathrm{~b}$. There is decrease in the value of ecosystem services from the current level ( $\$ 3.57$ billion in 2016) to $\$ 2.7$ billion and $\$ 2.5$ billion in Lacuna and Gold Coast SA scenarios, respectively. Whereas, the Down to Earth and Green $\mathcal{E}$ Gold scenarios show significantly higher ecosystem services values by 2050 ( $\$ 5.03$ billion).

There is significant decrease in annual total value of ecosystem services in Lacuna (decrease \$0.87 million) and Gold Coast SA (decrease by $\$ 1.07$ million) scenarios when adjusted values are used. Whereas, the annual value of ecosystem services increased (by $\$ 1.46$ million) in both Down to Earth and Green E Gold scenarios after adjusted values are used (Fig. 4, Table 4b).

Population projections under each scenario up to the year 2050 were estimated based on the current population numbers (ABS, 2016a) and changes based on stakeholder discussions held during the workshop (Fig. 5). The current population in the region is 327,344 with $1.4 \%$ growth rate (ABS, 2016a). Given the characteristics of the scenario, population projections are based on the growth rate of $0.5 \%$ (Lacuna), $2 \%$ (Gold Coast SA), 1\% (Down to Earth) and $1.5 \%$ (Green and Gold). With these projection assumptions, the population in highest in Gold Coast SA followed by Green $\mathcal{E}$ Gold, Down to Earth and Lacuna at 641816, 543063, 459125, 387838, respectively in 2050 . These are comparable with the current projected population of 525164 .

Current Gross Domestic Product (GDP) in the region is $\$ 14.7$ billion with a growth rate of $2.5 \%$ (ABS, 2016b). GDP in each of the four scenarios was also projected on the basis of workshop discussions and agreement on various rates of growth (Fig. 5). Rates of growth considered were 0.5\% Lacuna, 3.5\% Gold Coast SA, 1.5\% Down to Earth and 3\% Green and Gold. Based on these growth rates, the Gold Coast SA scenario is likely to have the highest GDP by the year 2050. With these growth rates, the projected GDP would be highest in Gold Coast SA at $\$ 47.3$ billion, followed by Green $\mathcal{E}$ Gold at $\$ 40.2$ billion, $\$ 24.4$ billion in Down to Earth and $\$ 17.4$ billion in Lacuna by 2050 . Under the current rate of GDP growth in the region it would be $\$ 34$ billion by 2050 .

There is inequality in the region with a Gini co-efficient of 0.33 (ABS, 2016b). Based on the discussions at the workshop, the inequality coefficient for each scenario was estimated. Lacuna would have 0.33 (no change from current situation), Gold Coast $S A$ showed increase in inequality (0.45). Whereas, there is decrease in inequality in Green $\mathcal{E}$ Gold (0.27) and Down to Earth (0.25) scenarios. 

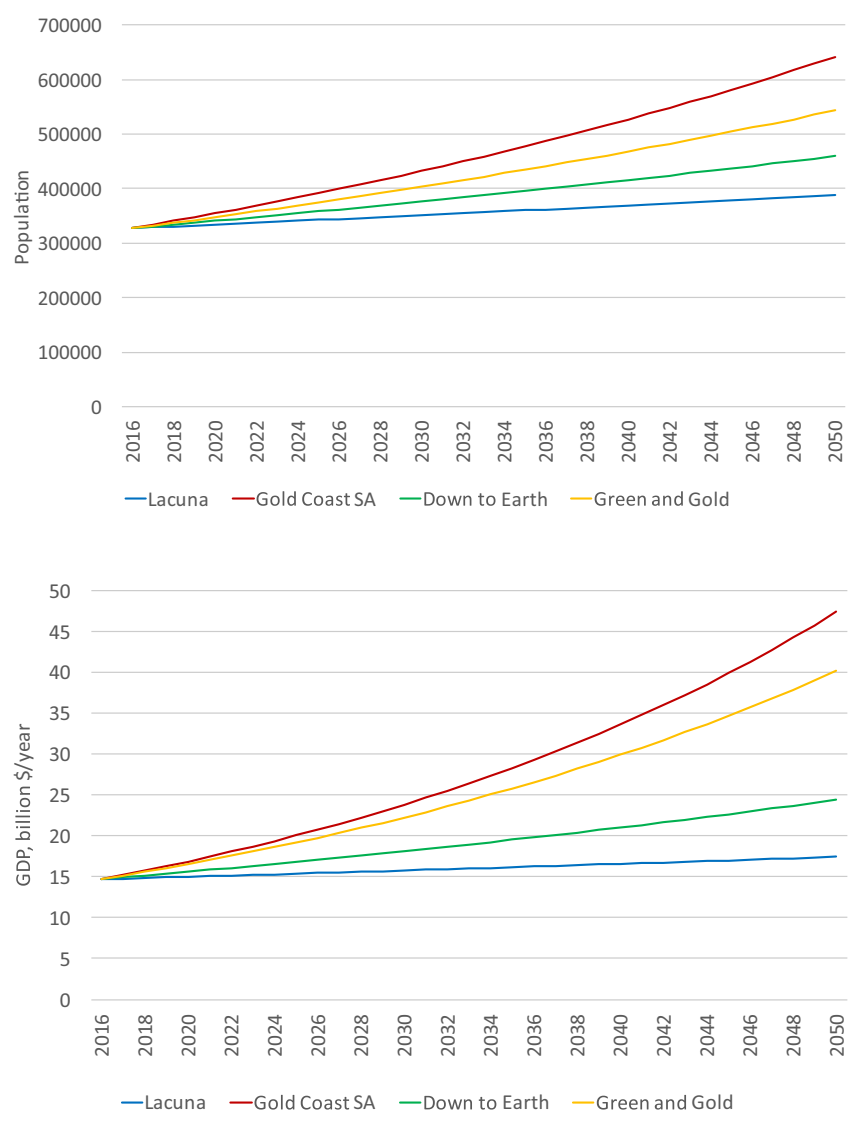

Fig. 5. Population and GDP for the current situation (in 2016) and in the four scenarios by 2050 in the BIPE region.

\section{Discussion}

\subsection{Key outcomes of scenarios}

The four scenarios represent different plausible futures for the BIPE region, differentiated by various economic, social and environmental attributes.

Lacuna scenario represent economic decline with decrease in GDP growth rate from current $2.5 \%$ to $0.5 \%$ by 2050 (Fig. 5). This is primarily due to lack of governance and little focus on planned economic development. This scenario represents business as usual approach, which is reflective of the current development in the region. BIPE region hosts about $19.5 \%$ of the South Australian population but its GDP is only $14.7 \%$ of the state GDP (ABS, 2016b). GDP per capita is lower at $\$ 44906$ as compared to the state average of $\$ 58922$ (ABS, 2016b). GDP per capita under this scenario further declines to $\$ 44864$, as compared to $\$ 64741$ at the current rate of growth by 2050 . Less employment opportunities leads to increasingly fragmented society with high inequality in income leading to poor socio-economic status of the residents. This leads to poor mental and physical health and overall well-being of residents. Ecosystem services are essential for human well-being (MEA, 2005), which are being degraded rapidly under Lacuna. This is also supported by our estimation of the total value of ecosystem services, which decreased significantly in 2050 due to lack of appreciation for the environment under this scenario (Table 4).

Gold Coast SA scenario promotes highest economic growth and population among all four scenarios (Fig. 5). Regional economy is driven by market centred approach as observed in similar market oriented scenarios in other exercises (Kubiszewski et al., 2016, 2017). Local policies support business and industry and encourages foreign investment with minimal regulation. GDP per capita increases to $\$ 73697$ by 2050 (Fig. 5). However, such policies result in high inequality ( 0.45 Gini co-efficient) in the society. Economic development is favoured over sustainable development, which promotes wealth generation for fewer individuals. Lower incomes of majority of the population leads to unhappiness and mental health issues. There is highest population growth amongst all scenarios. There is widespread degradation of environment supported by our estimations in decline of area under seagrass, saltmarsh, agriculture, green spaces etc. (Table 2). This also results in loss of vital ecosystem services and their economic value in the region (Table 4).

Down to Earth scenario represents moderate economic growth, which is oriented towards local production and consumption with greater emphasis on socially responsible business. This is achieved by creating a circular economy, which is committed to resource conservation. Such economic development is more inclusive and promotes equality, which is reflected by a Gini co-efficient of 0.25 as compared to the current situation of moderate inequality (0.33). GDP under this scenario grows at moderate $1.5 \%$, which is lower than the current 2.5\% (Fig. 5). Population also grows at lower than the current rate of growth, which results in moderate per capita GDP. It emphasises better quality of life and higher standards of living amongst all residents. There are employment opportunities for all segments of society. Due to integration of environment into economic development, this scenario leads to increase in area under saltmarsh, mangroves, green spaces and freshwater (Table 2), which results in high value of ecosystem services (Table 4).

Green and Gold scenario focuses on both high economic growth and higher attention to environment. GDP and population are only second to the Gold Coast SA scenario (Fig. 5).

Economy undergoes rapid transformation and is geared towards embracing new challenges and taking up new opportunities such as green technologies, renewable energy, sustainably grown food, innovative solutions etc. These promote strong economy much growth and provided employment to all residents. There is equality in the income distribution ( 0.27 Gini co-efficient). There is high GDP per capita at $\$ 74024$ by 2050 as compared to the $\$ 64741$ at the current rate of growth and current policies (Fig. 5). Better economic opportunities and good environment leads to longer life expectancy and increased happiness and health among individuals. This scenario also leads to increase in area under saltmarsh, mangroves, green spaces and freshwater (Table 2), which results in high value of ecosystem services, which is similar to that in Down to Earth scenario (Table 4).

\subsection{Future value of ecosystem services}

There is a long history of valuing ecosystem services and its use in analysing trade-offs under different scenarios (Costanza et al., 1997, 2014; Farber et al., 2002; Kubiszewski et al., 2017). Monetary values are being used as they allow same common denominator of all the elements for direct comparison of the trade-offs (Kubiszewski et al., 2017). However, it does not promote privatisation of ecosystem services. Some ecosystem services (such as regulating, some cultural and habitat services) are not exchanged in markets; therefore, their values are based on non-market use (Kubiszewski et al., 2010, 2017). We used economic values of ecosystem services in the current scenario analysis to complement other attributes such as GDP, inequality, governance, population etc. This study is an example of the use of valuation of ecosystem services in scenario planning.

The ecosystem service values for BIPE region would be lower than present under the Lacuna and Gold Coast SA scenarios, and higher than present under the Down to Earth and Green E Gold 
scenarios, reflecting the benefits of healthy, diverse and extensive coastal wetlands under these scenarios. Although these regional scale scenarios resemble global scenarios (Kubiszewski et al., 2016), there are specific implications for the future value of ecosystem services for the region. In contrast to the global scenarios where, ecosystem services are declining due to deterioration of habitats (Costanza et al., 2014; Sutton et al., 2016), the BIPE region scenarios, Down to Earth and Green \& Gold demonstrate that the appropriate policy response and management can result in increase in total value of ecosystem services (Table 4). Moreover, earlier studies resulted in key conclusion that the total value of ecosystem services is double than the global GDP (Costanza et al., 1997, 2014). However, applying benefit transfer in the regional context and with adjusting unit value and land cover area, it was found that, currently, the total value of ecosystem services in the BIPE region was one-fourth of the regional GDP. By 2050, under the Green and Gold, it will be one-eighth of the GDP (Fig. 5, Table 4b). The best scenario in terms of ecosystem services value was Down to Earth, with one-fourth of the GDP by 2050. These results point towards gaps in the appreciation of local value of ecosystem services and suggests attention of policy makers to consider such scenarios for regional planning.

The unit values per land cover were adjusted from 2011 values as described above. However, in order to show the sensitivity of the results to the changes in the 2011unit values, Fig. 4 and Table 4 provide results with and without changes to the unit values. The general trends and conclusions are unchanged, only the magnitudes are different. With changes in unit values, there is further decrease in total value of ecosystem services in Lacuna and Gold Coast SA scenarios (Fig. 4). Whereas, there is increase in total values by adjusting unit value in Down to Earth and Green and Gold scenarios (Fig. 4).

\subsection{Use in decision making}

The scenarios illustrate plausible futures that can guide comprehensive decision-making for future economic developments in regard to effects on the environment, ecosystem services, and human well-being. Scenario planning explicitly acknowledges ambiguity and uncertainty, which is captured under plausible scenarios described in this study. It provides a coherent picture of alternative futures. However, they are not predictions. Therefore, a plausible range of possible futures should be used cautiously in future planning. As 26 out of 55 participants represented local and state government, there was strong presence that demonstrates commitment from local decision-makers in crafting plausible future for the region. This should be viewed as an effective starting point for engagement. The inputs from government stakeholders provided linkages and references to the current and future development activities during the scenario analysis. For example, the current Northern Connector motorway can lead to decline of saltmarsh in Lacuna, and improved industrial activity in Gold Coast SA. Similarly, the current carbon neutral Adelaide plan (Government of South Australia, 2015), the Greater Adelaide plan by 2028 (Government of South Australia, 2010), were considered while developing each scenario. The implications of such development activity on the future value of ecosystem services can advance decision making and guide better regional planning. This approach can fill the gap identified by Marre et al. (2016) between the theory and practice of using ecosystem service valuation for coastal decision making. However, given the complex governance structure in the region, flow of ecosystem services, current economic activities, there is immediate challenge to identify and engage change agents (Bohensky et al., 2011).

\subsection{Challenges and limitations}

This study develops four plausible scenarios for the BIPE region and analyse the implications for the value of ecosystem services to the year 2050 along with other attributes such as GDP, inequality, population etc. It uses several simplifying assumptions to develop these scenarios and estimate the value of ecosystem services, such as:

The effects of longer-term changes with regards to adaptation to climate change (Picketts et al., 2012) and sea-level rise were not fully captured. There is also need to understand the unintended consequences of climate change and other important drivers, and trade-offs for achieving social, environmental and economic development (Butler et al., 2016).

There is also further scope to enhance our understanding of local ecological knowledge by involving indigenous community groups.

Ecosystem services valuation is used as one aspect of the assessment in scenario planning for the BIPE region. This study does not focus on advancing methods for the valuation of ecosystem services. Unit values of ecosystem services, ranging from $\$ 340$ to 265,000 per hectare per year, in various land cover classes used in the study were based on global studies that used these unit values to estimate future value of ecosystem services under different scenarios (Costanza et al., 2014; Kubiszewski et al., 2017). Using this simplified approach obviously limits the accuracy of the results for total value of ecosystem services in each scenario. We believe they do not, change the general conclusions, however, as these are scenarios, not predictions.

Changes in ecosystem services value are assumed to be due to changes in land use and management. Changes due to relative scarcity, demand, or quality are not modelled in the analysis.

The per unit area values for ecosystem services by land cover class are assumed to be constant over space.

Annual variation in the value of ecosystem services is anticipated due to external factors such as economic fluctuations and specific climate conditions (drought/flood/hotter or colder years), however, calculations and graphs represent a smoothed average change until 2050.

Scenario planning explicitly acknowledges ambiguity and uncertainty, which is captured under plausible scenarios described in this study. It provides a coherent picture of alternative futures. However, they are not predictions. Therefore, a plausible range of possible futures should be used cautiously in future planning (Costanza et al., 2015; Kubiszewski et al., 2016, 2017).

\section{Conclusions}

This paper presents the process for developing plausible scenarios for the Barker Inlet and Port River Estuary region as a tool to aid decision making. It supports these plausible scenarios with the future value of ecosystem services. We emphasise that the valuation of ecosystem services is admittedly quick and straightforward. Moreover, the unit values of ecosystem services are not precise estimates of the present or predictions of the future. However, it is an attempt to use scenario planning to provide a spectrum of possibilities (Costanza et al., 2014; Kubiszewski et al., 2016, 2017). These scenarios were intended to inform planning processes about different plausible futures for this region. Scenario planning models the effect of changes to land use based on social, environment and economic variables. Scenario planning can be seen as an experimental learning approach that can improve social learning for proactive decision making in response to complex issues on coastal governance (Clarke et al., 2013; Nursey-Bray et al., 2016). The creation of four scenarios and future value of ecosystem 
services to 2050 , provides a solid starting point for the development of a decision-support system for this coastal region. However, further consultation with general public and decision makers in government agencies, industry, NGOs and community groups is required for the possibility of their inclusion in local and state level planning. Such a process can also be adapted to coastal environments elsewhere to support future management decision making.

\section{Acknowledgements}

Authors thank the Adelaide and Mount Lofty Ranges Natural Resources Management Board for financial support for the project. Authors also acknowledge the contribution by University of South Australia students Michael Dyer, Anastasia Martinez and Briony Ankor for their help during the workshop. Initial funding from the Barbara Hardy Institute, University of South Australia and Flinders University, Australia is acknowledged. We sincerely thank all workshop participants for their contributions and lively discussions during the workshop and sharing their stakeholder perspectives.

\section{References}

ABS, 2016a. Australian Demographic Statistics, 2016. Australian Bureau of Statistics. http://www.abs.gov.au/Population.

ABS, 2016b. Australian National Accounts: National Income, Expenditure and Product, Dec 2016. http://www.abs.gov.au.

Arkema, K.K., Verutes, G.M., Wood, S.A., Clarke-Samuels, C., Rosado, S., Canto, M., Guerry, A.D., 2015. Embedding ecosystem services in coastal planning leads to better outcomes for people and nature. PNAS 112 (24), 7390-7395. https://doi. org/10.1073/pnas.1406483112.

Barbier, E.B., Hacker, S.D., Kennedy, C., Koch, E.W., Stier, A.C., Silliman, B.R., 2011. The value of estuarine and coastal ecosystem services. Ecol. Monogr. 81, 169193.

Bateman, I.J., Harwood, A.R., Mace, G.M., Watson, R.T., Abson, D.J., Andrews, B., Binner, A., Crowe, A., Day, B.H., Dugdale, S., Fezzi, C., Foden, J., Hadley, D., Haines-Young, R., Hulme, M., Kontoleon, A., Lovett, A.A., Munday, P., Pascual, U., Paterson, J., Perino, G., Sen, A., Siriwardena, G., van Soest, D., Termansen, M., 2013. Bringing ecosystem services into economic decision-making: land use in the United Kingdom. Science 341, 45-50.

Bloomfield, A.L., Gillanders, B.M., 2005. Fish and invertebrate assemblages in seagrass, mangrove, saltmarsh, and nonvegetated habitats. Estuaries 28, 63-77.

Bohensky, E., Butler, J.R.A., Costanza, R., Bohnet, I., Delisle, A., Fabricius, K., Gooch, M., Kubiszewski, I., Lukacs, G., Pert, P., Wolanski, E., 2011. Future makers or future takers? A scenario analysis of climate change and the Great Barrier Reef. Global Environ. Change 21, 876-893.

Butler, J.R.A., Bohensky, E.L., Suadnya, W., Yanuartati, Y., Handayani, T., Habibi, P., Puspadi, K., Skewes, T.D., Wise, R.M., Suharto, I., Park, S.I., Sutaryono, Y., 2016. Scenario planning to leap-frog the sustainable development goals: an adaptation pathways approach. Clim. Risk Manage. 12, 83-99.

Carlsson, J., Eriksson, L.O., Öhman, K., Nordström, E.-M., 2015. Combining scientific and stakeholder knowledge in future scenario development - A forest landscape case study in northern Sweden. Forest Policy Econ. 61, 122-134.

Caton, B., Fotheringham, D., Krahnert, E., Pearson, J., Royal, M., Sandercock, R., 2009. Metropolitan Adelaide and Northern Coastal Action Plan. Prepared for the Adelaide and Mount Lofty Ranges NRM Board and Department for Environment and Heritage.

Clarke, B., Stocker, L., Coffey, B., Leith, P., Harvey, N., Baldwin, C., Baxter, T., Bruekers, G., Galano, C.D., Good, M., Haward, M., Hofmeester, C., De Freitas, D.M., Mumford, T., Nursey-Bray, M., Kriwoken, L., Shaw, J., Shaw, J., Smith, T., Thomsen, D., Wood, D., Cannard, T., 2013. Enhancing the knowledgegovernance interface: coasts, climate and collaboration. Ocean Coast. Manag. 86, 88-99.

Coleman, P., Cook, F., 2009. Shorebird Management and Conservation. Report for the Adelaide \& Mt Lofty Ranges Natural Resources Management Board, Adelaide.

Connolly, R.M., 1994. A comparison of fish assemblages from seagrass and unvegetated areas of a southern Australian estuary. Aust. J. Mar. Freshw. Res. 45, 1033-1044.

Costanza, R., d’Arge, R., De Groot, R., Farber, S., Grasso, M., Hannon, B., Limburg, K., Naeem, S., O’Neill, R.V., Paruelo, J., Raskin, R.G., Sutton, P., van den Belt, M., 1997. The value of the world's ecosystem services and natural capital. Nature 387, 253-260.

Costanza, R., de Groot, R., Sutton, P., van der Ploeg, S., Anderson, S.J., Kubiszewski, I., Farber, S., Turner, R.K., 2014. Changes in the global value of ecosystem services. Global Environ. Change 26, 152-158.

Costanza, R., Kubiszewski, I., Cork, S., Atkins, P.W.B., Bean, A., Diamond, A., Grigg, N., Korb, E., Logg-Scarvell, J., Navis, R., Patrick, K., 2015. Scenarios for Australia in 2050: a synthesis and proposed survey. J. Futures Stud. 19, 49-76.
Cribb, N., Miller, C., Seuront, L., 2013. Indo-Pacific bottlenose dolphin (Tursiops aduncus) habitat preference in a heterogeneous, urban, coastal environment. Aquat. Biosyst. 9, 3.

Department of Climate Change, 2009. Climate change risks to Australia's coasts: a first pass national assessment. http://www.environment.gov.au/climatechange/adaptation/publications/climate-change-risks-australias-coasts.

Edwards, J.W., Edyvane, K.S., Boxall, V.A., Hamann, M., Soole, K.L., 2001. Metal levels in seston and marine fish flesh near industrial and metropolitan centres in South Australia. Mar. Pollut. Bull. 42, 389-396.

Edyvane, K.S., 1999. Coastal and marine wetlands in Gulf St. Vincent, South Australia: understanding their loss and degradation. Wetlands Ecol. Manage. 7 83-104.

Ellis, J.I., Hewitt, J.E., Clark, D., Taiapa, C., Patterson, M., Sinner, J., Hardy, D., Thrush, S.F., 2015. Assessing ecological community health in coastal estuarine systems impacted by multiple stressors. J. Exp. Mar. Biol. Ecol. 473, 176-187.

Farber, S.C., Costanza, R., Wilson, M.A., 2002. Economic and ecological concepts for valuing ecosystem services. Ecol. Econ. 41 (3), 375-392.

Fotheringham, D., Coleman, P., 2008. Salt Marshes. In: Shepherd, S.A., Bryars, S. Kirkegaard, I., Harbison, P., Jennings, J.T. (Eds.), Natural History of Gulf St Vincent. Royal Society of South Australia Inc., Adelaide, pp. 81-94.

Fowler, A.J., Short, D.A., 1996. Temporal variation in the early life-history characteristics of the King George whiting (Sillaginodes punctata) from analysis of otolith microstructure. Mar. Freshw. Res. 47, 809-818.

Gini, C., 1936. On the measure of concentration with special reference to income and statistics. Colorado College Publication, General Series No. 208, 73-79.

Government of South Australia, 2010. The 30-Year Plan for Greater Adelaide. In: Department of Planning and Local Government, Adelaide

Government of South Australia, 2015. Carbon Neutral Adelaide: A shared vision for the world's first carbon neutral city. https://www.environment.sa.gov.au/ Science/Science_research/climate-change/climate-change-initiatives-in-southaustralia/sa-climate-change-strategy/carbon-neutral-adelaide.

IPCC, 2000. Special Report on Emissions Scenarios. A Special Report of Working Group III of the Intergovernmental Panel on Climate Change. Cambridg University Press, Cambridge, UK.

Jackson, G., Jones, G.K., 1999. Spatial and temporal variation in nearshore fish and macroinvertebrate assemblages from a temperate Australian estuary over a decade. Mar. Ecol. Prog. Ser. 182, 253-268.

Kahane, A., 2004. Solving Tough Problems: An Open Way of Talking, Listening, and Creating New Realities. Berrett-Koehler Publishers, San Francisco.

Kemper, C., Bossley, M., Shaughnessy, P., 2008. Marine Mammals of Gulf St Vincent, Investigator Strait and Backstairs Passage. In: Shepherd, S.A., Bryars, S. Kirkegaard, I., Harbison, P., Jennings, J.T. (Eds.), Natural History of Gulf St Vincent. Royal Society of South Australia Inc., Adelaide, pp. 339-352.

Kubiszewski, I., Farley, J., Costanza, R., 2010. The production and allocation of information as a good that is enhanced with increased use. Ecol. Econ. 69, 13441354.

Kubiszewski, I., Anderson, S., Costanza, R., Sutton, P., 2016. The future of ecosystem services in Asia and the Pacific. Asia \& the Pacific Policy Studies 3, 389-404.

Kubiszewski, I., Costanza, R., Anderson, S., Sutton, P., 2017. The future value of ecosystem services: global scenarios and national implications. Ecosystem Services 26 Part A, 289-301.

Liquete, C., Piroddi, C., Drakou, E.G., Gurney, L., Katsanevakis, S., Charef, A., Egoh, B. 2013. Current status and future prospects for the assessment of marine and coastal ecosystem services: a systematic review. PLOS ONE 8, e67737.

Luisetti, T., Jackson, E.L., Turner, R.K., 2013. Valuing the European 'coastal blue carbon' storage benefit. Mar. Pollut. Bull. 71, 101-106.

Marre, J.B., Thébaud, O., Pascoe, S., Jennings, S., Boncoeur, J., Coglan, L., 2016. Is economic valuation of ecosystem services useful to decision-makers? Lessons learned from Australian coastal and marine management. J. Environ. Manage. $178,52-62$.

Martinez-Harms, M.J., Bryan, B.A., Figueroa, E., Pliscoff, P., Runting, R.K., Wilson, K. A., 2017. Scenarios for land use and ecosystem services under global change. Ecosyst. Serv. 25, 56-68.

MEA, 2005. Millennium Ecosystem Assessment Synthesis Report. Island Press, Washington.

Mistry, J., Tschirhart, C., Verwer, C., Glastra, R., Davis, O., Jafferally, D., et al., 2014 Our common future? Cross-scalar scenario analysis for social-ecological sustainability of the Guiana Shield, South America. Environ. Sci. Policy 44 $126-148$.

Neumann, B., Vafeidis, A.T., Zimmermann, J., Nicholls, R.J., 2015. Future coastal population growth and exposure to sea-level rise and coastal flooding - A Global Assessment. Plos One 10.

Nursey-Bray, M., Harvey, N., Smith, T.F., 2016. Learning and local government in coastal South Australia: towards a community of practice framework for adapting to global change. Reg. Environ. Change 16, 733-746.

O’Brien, P., 2000. Scenario Planning: A Strategic Tool. Bureau of Rural Sciences, Canberra.

Outeiro, L., Häussermann, V., Viddi, F., Hucke-Gaete, R., Försterra, G., Oyarzo, H., Kosiel, K., Villasante, S., 2015. Using ecosystem services mapping for marine spatial planning in southern Chile under scenario assessment. Ecosyst. Serv. 16, 341-353.

Peterson, G.D., Cumming, G.S., Carpenter, S.R., 2003. Scenario planning: a tool for conservation in an uncertain world. Conserv. Biol. 17, 358-366.

Phillips-Mao, L., Galatowitsch, S.M., Snyder, S.A., Haight, R.G., 2016. Model-based scenario planning to develop climate change adaptation strategies for rare plant populations in grassland reserves. Biol. Conserv. 193, 103-114. 
Picketts, I.M., Werner, A.T., Murdock, T.Q., Curry, J., Déry, S.J., Dyer, 2012. Planning for climate change adaptation: lessons learned from a community-based workshop. Environ. Sci. Policy 17, 82-93.

Poch, R.M., Thomas, B.P., Fitzpatrick, R.W., Merry, R.H., 2009. Micromorphological evidence for mineral weathering pathways in a coastal acid sulfate soil sequence with Mediterranean-type climate, South Australia. Aust. J. Soil Res. 47, 403-422.

Podolak, K., Lowe, E., Wolny, S., Nickel, B., Kelsey, R., 2017. Informing watershed planning and policy in the Truckee River basin through stakeholder engagement, scenario development, and impact evaluation. Environ. Sci. Policy 69, 124-135.

Purnell, C., Peter, J., Clemens, R., 2015. Shorebird Population Monitoring within the Gulf St Vincent: July 2014 to June 2015 Annual Report. BirdLife Australia Report for the Adelaide \& Mt Lofty Ranges Natural Resources Management Board.

Reed, M.S., Kenter, J., Bonn, A., Broad, K., Burt, T.P., Fazey, I.R., Fraser, E.D.G., Hubacek, K. Nainggolan, D., Quinn, C.H., Stringer, L.C., Ravera, F., 2013. Participatory scenario development for environmental management: A methodological framework illustrated with experience from the UK uplands. J. Environ. Manage. 128, 345-362.

Ruiz-Mallén, I., Corbera, E., Calvo-Boyero, D., Reyes-Garcia, V., 2015. Participatory scenarios to explore adaptation to global change in biosphere reserves: experiences from Bolivia and Mexico. Environ. Sci. Policy 54, 398-408.

Shepherd, S.A., Bryars, S., Kirkegaard, I., Harbison, P., Jennings, J.T., 2008. Natural History of Gulf St Vincent. Royal Society of South Australia Inc., Adelaide.
Sutton, P.C., Anderson, S.J., Costanza, R., Kubiszewski, I., 2016. The ecological economics of land degradation: impacts on ecosystem service values. Ecol. Econ. 129, 182-192.

Tammi, I., Mustajärvi, K., Rasinmäki, J., 2017. Integrating spatial valuation of ecosystem services into regional planning and development. Ecosyst. Serv. 26, 329-344. https://doi.org/10.1016/j.ecoser.2016.11.008.

TEEB, 2010. The Economics of Ecosystems and Biodiversity Ecological and Economic Foundations. Edited by Pushpam Kumar. Earthscan, London and Washington. http://www.teebweb.org.

Turner, K.G., Anderson, S., Gonzales-Chang, M., Costanza, R., Courville, S., Dalgaard, T., Dominati, E., Kubiszewski, I., Ogilvy, S., Porfirio, L., Ratna, N., Sandhu, H., Sutton, P.C., Svenning, J.-C., Turner, G.M., Varennes, Y.-D., Voinov, A., Wratten, S., 2016. A review of methods, data, and models to assess changes in the value of ecosystem services from land degradation and restoration. Ecolog. Model. 319, 190-207.

UNEP, 2010. Latin America and the Caribbean Environment Outlook: GEO LAC 3. UNEP, Panama.

Wang, Q.J., Soste, L., Robertson, D., Handley, S. \& Chaffe, R., 2006. Scenario planning for irrigation futures of the Goulburn Broken Region. Practice Change for Sustainable Communities: Exploring Footprints, Pathways and Possibilities. In: Proceedings of the Australasia Pacific Extension Network International Conference, 6-8 March, Beechworth, Victoria, Australia. ISBN 1920842314 